Article

\title{
Antigenotoxic Effect of Piperine in Broiler Chickens Intoxicated with Aflatoxin B1
}

\author{
Verônica da Silva Cardoso ${ }^{1, *}$, Alane Beatriz Vermelho ${ }^{1, *}$, Cristina Amorim Ribeiro de Lima ${ }^{2}$, \\ Jéssica Mendes de Oliveira ${ }^{3}$, Marco Edilson Freire de Lima ${ }^{4}$, Lúcia Helena Pinto da Silva ${ }^{3}$, \\ Glória Maria Direito ${ }^{3}$ and Maria das Graças Miranda Danelli ${ }^{3}$
}

1 BIOINOVAR - Biotecnologia, Unidade de Biocatálise, Bioprodutos e Bioenergia, Instituto de Microbiologia Paulo de Góes, Universidade Federal do Rio de Janeiro, Rio de Janeiro, RJ 21941-901, Brazil

2 Instituto de Zootecnia, Universidade Federal Rural do Rio de Janeiro, Seropédica, RJ 23890-000, Brazil; criblima@terra.com.br

3 Instituto de Veterinária, Universidade Federal Rural do Rio de Janeiro, Seropédica, RJ 23890-000, Brazil; jessicamop@hotmail.com (J.M.d.O.); lpinto_silva@yahoo.com (L.H.P.d.S.); gdireito@ufrrj.br (G.M.D.); danelli@ufrrj.br (M.d.G.M.D.)

4 Instituto de Ciências Exatas, Universidade Federal Rural do Rio de Janeiro, Seropédica, RJ 23890-000, Brazil; marco@ufrrj.br

* Correspondence: verocardoso@micro.ufrj.br (V.d.S.C.); abvermelho@micro.ufrj.br (A.B.V.); Tel.: +55-21-3936-6743 (V.d.S.C. \& A.B.V.)

Academic Editor: Isabelle P. Oswald

Received: 16 August 2016; Accepted: 27 October 2016; Published: 31 October 2016

\begin{abstract}
Piperine is an abundant amide extracted from black pepper seeds which has been shown to have protective effects against cytotoxic and genotoxic carcinogenesis induced by certain chemical carcinogens and aflatoxin $\mathrm{B}_{1}\left(\mathrm{AFB}_{1}\right)$ in vitro. The aim of this work was to study, in vivo, the antigenotoxic potential of feed-added piperine on broiler chickens experimentally intoxicated with $\mathrm{AFB}_{1}$, using micronucleus and comet assays. The antigenotoxicity assessment of 9-day-old chicks was performed on a total of 60 chickens divided into four groups of 15 broilers each: (C) control, (P) $60 \mathrm{mg} \cdot$ piperine $\mathrm{kg}^{-1}$ feed, (A) $0.5 \mathrm{mg} \cdot \mathrm{AFB}_{1} \cdot \mathrm{kg}^{-1}$ body weight, (daily by oral route), and $(\mathrm{P}+\mathrm{A})$ co-treatment with piperine and $\mathrm{AFB}_{1}$. The experiment was conducted for 26 days. Chicks intoxicated with $\mathrm{AFB}_{1}$ showed significant genotoxic effects in the first $24 \mathrm{~h}$ post intoxication, and the effects remained in the other periods analyzed (48, 72, and $96 \mathrm{~h}$ and 26 days of treatment). The DNA damage in peripheral blood cells, the number of erythrocytes with micronuclei, and polychromatic-to-normochromatic erythrocyte ratio were significantly reduced or absent in the piperine $/ \mathrm{AFB}_{1}$ group. No significant differences were observed between the group piperine $/ \mathrm{AFB}_{1}$ and the control and piperine-alone groups. The addition $60 \mathrm{mg} \cdot \mathrm{kg}^{-1}$ of piperine to the diet of the broiler chicks was safe, promoting beneficial effects in poultry health with respect to the toxic effects $0.5 \mathrm{mg} \cdot \mathrm{AFB}_{1} \cdot \mathrm{kg}^{-1}$ body weight.
\end{abstract}

Keywords: aflatoxin $\mathrm{B}_{1}$; broiler chicken; piperine; Aspergillus

\section{Introduction}

Aflatoxicosis is a disease resulting from the ingestion of aflatoxin in contaminated food and feed, and has become one of the most widespread and important diseases in the poultry industry [1-3]. Moreover, the increased human consumption of chicken has placed new demands on the poultry industry which require adaptation. Today, most consumer products are required to be safe and free of pathogens or substances that could be harmful to human health [4-7].

Aflatoxins are secondary metabolites produced by certain strains of fungi of the genus Aspergillus. The aflatoxins of interest to health care include aflatoxin $B_{1}\left(A_{F} B_{1}\right)$, aflatoxin $B_{2}$, aflatoxin $G_{1}$, 
and aflatoxin $G_{2}$ [8]. $A F B_{1}$ is the subtype most commonly found in contaminated foods, and is considered the most toxic of the subtypes, followed by aflatoxin $G_{1}, G_{2}$, and $B_{2}[9,10]$. Aflatoxins are chemically stable and it is difficult to inactivate them through physical or chemical methods [9]. Consequently, when present in a feed substrate, the processing methods used to produce the feed are incapable of eliminating these toxins, or even diminishing their concentration to any significant extent [10-14].

The biotransformation of aflatoxins varies according to the species, but other factors also influence their metabolism, such as the gender, age, health, and diet of the host [10]. The mechanism of $\mathrm{AFB}_{1}$ biotransformation has been studied with great interest, since it is closely correlated with its toxic action $[15,16]$. Aflatoxin $B_{1}$ is among the most potent of all the toxins known for their genotoxic effects, and is able to induce chromosomal aberrations, increased frequency of micronuclei development, sister chromatid exchange, unscheduled DNA synthesis, chromosome breakage, and formation of adducts in human and rodent cells [17-23].

The ever-increasing importance of plants with medicinal properties and their respective constituents in animal feed has increased the amount of research on different phytogenic compounds added either as dry or aqueous extracts, or as essential oils to the diet of animals, including broiler chickens. These additives act as performance enhancers, improving the quality of the feed for poultry [24,25].

Piperine (1-piperonyl piperidine) is an active amide present in various species of pepper, especially black pepper (Piper nigrum Linn.), and is responsible for the intense aroma of pepper. In addition, piperine may be found in all parts of the plant [26]. Recent studies have shown that the consumption of piperine is relatively safe, with low toxicity to cells of mammals and avian species [27-31]. Piperine has several biological and pharmacological properties, such as insecticidal [32], antiparasitic [33], antipyretic, analgesic, anti-inflammatory [34], and antioxidant activities [35,36]. Also, piperine has been shown to increase the bioavailability of some drugs in the body and decrease the cytotoxicity of $\mathrm{AFB}_{1}$ and genotoxicity in vitro without leaving residues or its derivatives in the host $[37,38]$. Suresh and Srinivasan [39] showed that the amount of piperine in rat tissues (0.3\%) reduced significantly after $48 \mathrm{~h}$, and was no longer detectable in the blood, liver, and intestine after $96 \mathrm{~h}$.

Recently, Zhang et al. [25] demonstrated the chemopreventive abilities of piperine against two osteosarcoma cell lines (HOS and U-2OS) metastasis and Greenshields et al. [40] demonstrated its protective properties against cancer cell migration in vitro through the inhibition of matrix metalloproteinase- 2 and -9 expression.

The interference of piperine in the aflatoxin mechanism of action, however, has been minimally studied. Reen et al. [37] showed that piperine was able to significantly decrease the toxicity of $\mathrm{AFB}_{1}$ in rat hepatocytes in vitro and Selvendiran et al. [41,42] demonstrated the protective effects of piperine against cytotoxic and genotoxic carcinogenesis induced by certain chemical carcinogens and $\mathrm{AFB}_{1}$. Gagini et al. [43] showed that piperine treatment in intoxicated rats decreased hepatic injuries and leukocyte depletion over a 23 day-period. Previous studies by our group have demonstrated that piperine intake decreased the severity of the toxic effects of aflatoxins in broiler chickens, preventing the development of liver injury and the adverse effects on hematological parameters, which are characteristic of aflatoxicosis. These data suggest that piperine might be used to prevent the effects of aflatoxin ingestion [44]. The poultry industry seeks the development of a feed additive with a natural, non-toxic substance such as piperine not only to promote the improvement of poultry health but also to contribute to increased productivity in this industry. Piperine can be easily obtained and purified, it leaves no detectable residues in meat and meat products, and it isalso able to protect against the toxic effects of $\mathrm{AFB}_{1}$. Owing to the vastness of the Brazilian territory, it is still difficult to implement and enforce existing laws and regulations for the control of aflatoxins in animal feed. However, the current ceiling for aflatoxins in poultry production is $50 \mu \mathrm{g} \cdot \mathrm{kg}^{-1}\left(B_{1}+B_{2}+G_{1}+G_{2}\right)$ for all nutrients for chickens during the initial, developing, and final stages of growth, according to Brazilian legislation (MAPA) [45]. In Europe the limit is $20 \mu \mathrm{g} \cdot \mathrm{kg}^{-1}$ [46] for aflatoxin $\mathrm{B}_{1}$ and in the USA the 
legislation determines that the concentration should not exceed $20 \mu \mathrm{g} \cdot \mathrm{kg}^{-1}$, calculated as the sum of the aflatoxins $B_{1}+B_{2}+G_{1}+G_{2}$ [47].

Brazil is the largest exporter and third largest producer of chicken in the world. Contamination with aflatoxins in poultry is a common problem in Brazil. Rossi et al. [48] detected aflatoxins in $72.1 \%$ of feed samples at average levels ranging from $0.0022 \mathrm{mg} \cdot \mathrm{kg}^{-1}$ (pre-starter) to $0.0064 \mathrm{mg} / \mathrm{kg}$ (grower). Piperine potentially could be used as a neutralizing factor for aflatoxin $B_{1}$. Reen et al. [37] showed that piperine protects rat cells in vitro by impairing the generation of toxic metabolites mediated by CYP4502B1 dependent activation of $\mathrm{AFB}_{1}$. This data motivates the present study. The study aimed to analyze the antigenotoxic capacity of piperine as a feed additive and its effect on the toxicity of aflatoxin $\mathrm{B}_{1}$ in vivo using broiler chickens (Gallus gallus).

\section{Results and Discussion}

The addition of phytobiotics to chicken feed has been investigated with great interest by various researchers. Some phytobiotics act as growth promoters and others can neutralize the toxic effects of xenobiotics like $\mathrm{AFB}_{1}[43,49,50]$. The covalent bonding of $\mathrm{AFB}_{1}$-epoxide with DNA modifies the structure of the nucleic acid and biological activity, generating RNA and DNA adducts with potential mutagenic, carcinogenic and teratogenic characteristics [51].

The supplementation of piperine in aflatoxin contaminated broiler diets maintained production rates in early stage, growth and total period significantly when compared to aflatoxin without piperine. Table 1 summarizes the results obtained with this comparison. No significant difference in feed conversion was observed between the piperine, piperine with aflatoxin, and negative control groups. It is interesting to note that in the first period (9 to 21 days) $\mathrm{AFB}_{1}$ interfered negatively in the weight gain (WG) and in the feed conversion (FC). In the second period (22 to 35 days), this was not observed. The $\mathrm{AFB}_{1}$ toxin acts slowly leading to irreparable losses in breeding. Often, cases go misdiagnosed, leading to irreparable losses in breeding. Usually there is a decreased ability to metabolize fats, starches and proteins, as well as apetite loss and the appearance of other metabolic disorders. However when analyzed throughout the total period (9-35 days) we observed a significant decrease in the WG and FC. This is probably a consequence of the initial stage in which the birds are more sensitive to the effects of $\mathrm{AFB}_{1}$.

Table 1. Effect of piperine on: feed intake (FI), weight gain (WG) and feed conversion (FC) during the early stage ( 9 to 21 days), growth stage (22 to 35 days) and total period ( 9 to 35 days) for the broiler treatment groups.

\begin{tabular}{cccccc}
\hline \multirow{2}{*}{ Parameters ${ }^{\mathbf{1}}$} & \multicolumn{5}{c}{ Treatments (ppm) } \\
\cline { 2 - 6 } & CONTROL & PIPERINE (P) & AFB $_{\mathbf{1}}(\mathbf{A})$ & $\mathbf{P}+\mathbf{A}$ & $\mathbf{C V}^{*}$ \\
\hline 9 to 21 days & & & & \\
\hline FI (g) & $1057^{\mathrm{a}} \pm 36.77$ & $1073^{\mathrm{a}} \pm 32.91$ & $1059^{\mathrm{a}} \pm 21.63$ & $1082^{\mathrm{a}} \pm 13.32$ & 2.46 \\
WG (g) & $679.3^{\mathrm{a}} \pm 43.50$ & $692.0^{\mathrm{a}} \pm 25.53$ & $609.30^{\mathrm{b}} \pm 31.39$ & $692.70^{\mathrm{a}} \pm 16.80$ & 4.42 \\
FC & $1.55^{\mathrm{a}} \pm 0.05$ & $1.54^{\mathrm{a}} \pm 0.02$ & $1.74^{\mathrm{b}} \pm 0.06$ & $1.56^{\mathrm{a}} \pm 0.02$ & 2.38 \\
\hline 22 to 35 days & & & & \\
\hline FI (g) & $2220^{\mathrm{a}} \pm 75.42$ & $2270^{\mathrm{a}} \pm 109.00$ & $2339^{\mathrm{a}} \pm 82.39$ & $2252^{\mathrm{a}} \pm 46.87$ & 3.45 \\
WG (g) & $1359^{\mathrm{a}} \pm 20.98$ & $1444^{\mathrm{a}} \pm 55.51$ & $1320^{\mathrm{a}} \pm 68.15$ & $1391^{\mathrm{a}} \pm 48.04$ & 3.50 \\
FC & $1.63^{\mathrm{a}} \pm 0.05$ & $1.57^{\mathrm{a}} \pm 0.05$ & $1.77^{\mathrm{b}} \pm 0.06$ & $1.61^{\mathrm{a}} \pm 0.02$ & 2.80 \\
\hline 9 to 35 days & & & & \\
\hline FI (g) & $3274^{\mathrm{a}} \pm 98.83$ & $3343^{\mathrm{a}} \pm 114.50$ & $3365^{\mathrm{a}} \pm 74.73$ & $3334^{\mathrm{a}} \pm 59.36$ & 2.61 \\
WG (g) & $2039^{\mathrm{a}} \pm 63.54$ & $2137^{\mathrm{a}} \pm 35.27$ & $1929^{\mathrm{b}} \pm 37.00$ & $2064^{\mathrm{a}} \pm 81.09$ & 2.23 \\
FC & $1.60^{\mathrm{a}} \pm 0.05$ & $1.56^{\mathrm{a}} \pm 0.04$ & $1.71^{\mathrm{b}} \pm 0.02$ & $1.61^{\mathrm{a}} \pm 0.04$ & 2.66 \\
\hline
\end{tabular}

Note: The data are expressed as mean \pm standard deviation of the group of 15 animals. The averages were compared by the Student-Newman-Keuls test. ${ }^{1}$ Coefficient of variation. ${ }^{a}, b$ values represented by the same letter are not statistically different $(p>0.05)$. ${ }^{*}$ Coefficients of variation $(\%) . \mathrm{AFB}_{1}$ : aflatoxin $\mathrm{B}_{1} ; \mathrm{A}: 0.5 \mathrm{mg} \cdot \mathrm{AFB}_{1} \cdot \mathrm{kg}^{-1}$ body weight; $\mathrm{P}: 60 \mathrm{ppm}$ piperine; $\mathrm{P}+\mathrm{A}: 60 \mathrm{mg}$ piperine $\cdot \mathrm{kg}^{-1}$ feed plus $0.5 \mathrm{mg} \cdot \mathrm{AFB}_{1} \cdot \mathrm{kg}^{-1}$ body weight. 
Our group previously demonstrated several histopathological alterations in broilers intoxicated with aflatoxin. We observed megalocytosis, mononuclear cell infiltrate regions, congestion of epithelial cells of the bile duct, necrosis of biliary ducts, vacuolar degeneration, edema and diffuse vacuolation of hepatocytes. These effects were not found in animals treated with piperine [44]. Cardoso et al. [31] evaluated the effect of piperine in different concentrations $\left(60,120\right.$, and $\left.180 \mathrm{mg} \cdot \mathrm{kg}^{-1}\right)$ for 35 consecutive days and the best and least toxic concentration was $60 \mathrm{mg} \cdot \mathrm{kg}^{-1}$.

Figure 1 represents in a graphic the percentage of DNA damage and Figure 2 showed the same damage through fluorescence microscope of peripheral blood cells in all groups. Both of the figures were developed based in the comet assay of the action of piperine on the genotoxic effects of aflatoxin $B_{1}$.
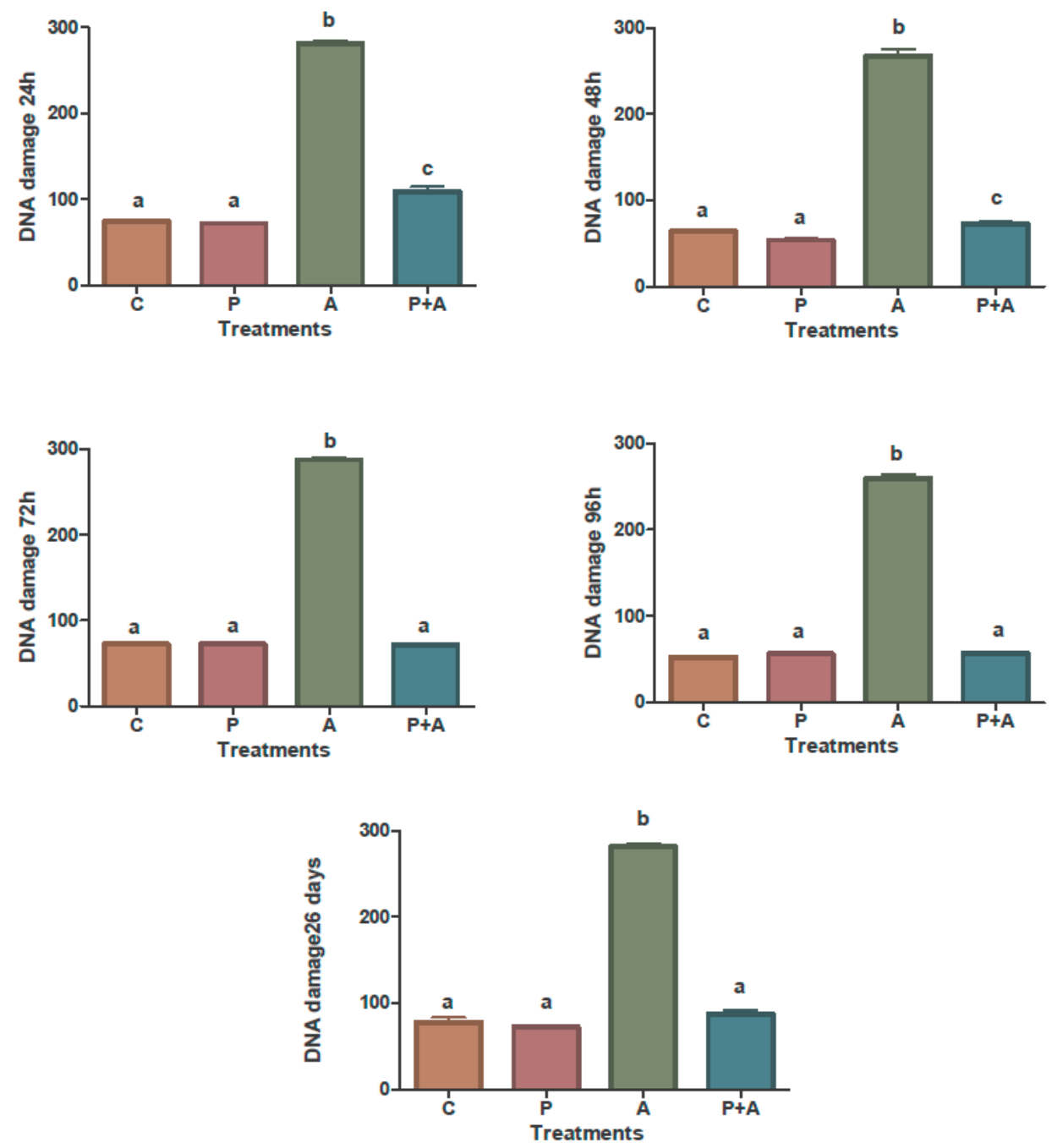

Figure 1. Comet assay of the action of piperine on the genotoxic effects of aflatoxin $B_{1}$ in peripheral blood of broiler chickens. C: Control group; P: $60 \mathrm{ppm}$ piperine; A: $0.5 \mathrm{mg} \cdot \mathrm{AFB}_{1} \cdot \mathrm{kg}^{-1} \mathrm{body}$ weight; $\mathrm{P}+\mathrm{A}: 60 \mathrm{mg}$ piperine $\cdot \mathrm{kg}^{-1}$ feed plus $0.5 \mathrm{mg} \cdot \mathrm{AFB}_{1} \cdot \mathrm{kg}^{-1}$ body weight; after $24,48,72$, and $96 \mathrm{~h}$, and 26 days of treatment. ${ }^{\text {a-c }}$ Means and standard deviation (error bars) compared by the Student-Newman-Keuls test; means with the same letters are not statistically different $(p>0.05)$. 

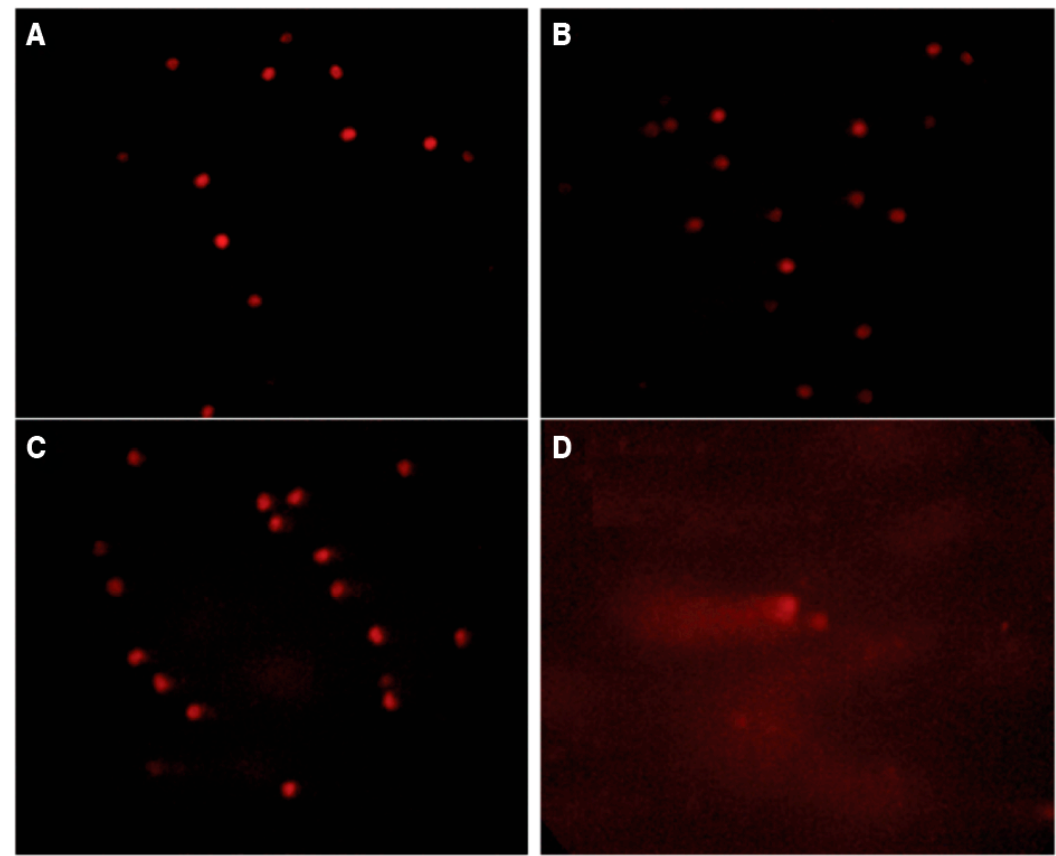

Figure 2. Comet assay. Damage to the DNA of peripheral blood cells was observed under an Olympus fluorescence microscope (Olympus BX41, Olympus Corporation, Tokyo, Japan) equipped with an excitation filter of 515-560 nm and a barrier filter of $590 \mathrm{~nm}(400 \times)$. One hundred cells were examined from each broiler. (A) Class 0 , control group fed soybean vehicle carrier only; (B) Class 1, control group with $60 \mathrm{mg} \cdot$ piperine $\cdot \mathrm{kg}^{-1}$ feed; (C) Class 2, group with piperine and $0.5 \mathrm{mg} \cdot \mathrm{AFB}_{1} \cdot \mathrm{kg}^{-1}$ body weight; (D) Class 3 , group with aflatoxin $\mathrm{B}_{1}$ only.

The results demonstrated that the feed with piperine added significantly reduced the genotoxic effects induced by $\mathrm{AFB}_{1}$. The results of the comparative analysis between the group of broiler chickens intoxicated with $\mathrm{AFB}_{1}$ and the intoxicated group that received the feed with piperine added indicated that $\mathrm{AFB}_{1}$ causes impaired erythropoiesis and significant damage to DNA, effects that the addition of $60 \mathrm{mg} \cdot \mathrm{kg}^{-1}$ of piperine was able to reduce or even eliminate. Such genotoxic injuries occur within a short time interval, and as such injuries could be seen $24 \mathrm{~h}$ post intoxication. They were still detectable at 48,72 , and $96 \mathrm{~h}$ and on day 26 . The broiler chickens that received only piperine showed no DNA damage (comet assay) and no increase in the number of cells with micronuclei; results that were similar to the control group $(p<0.05)$. The piperine $\left(60 \mathrm{mg} \cdot \mathrm{kg}^{-1}\right)$ added to the broiler feed was apparently safe, since no genotoxic effects were evident in the trials.

Heddle et al. [52] noted that micronuclei are a short-term response to a genotoxic substance, such that its expression is dependent on the intensity of exposure to pollution and probably independent of the duration of exposure. The formation of micronuclei has been widely used in molecular epidemiology as a biomarker of chromosomal damage and genomic instability [20]. Micronuclei are fragments of chromosomes or whole chromosomes left behind during the anaphase. The micronucleus test determines genotoxic effects and can be used not only for the detection of acute genetic damage but also for chronic damage [53]. The analysis of micronuclei in peripheral blood erythrocytes is applied when there is chronic exposure to a genotoxic product [54]. In this sense, the quantification of micronuclei in normochromatic erythrocytes reports on genotoxic events that occurred in a time equal to the lifetime of the circulating erythrocytes.

A significant increase was observed in micronuclei in normochromatic erythrocytes in the group of broilers treated with $\mathrm{AFB}_{1}$, indicating a chronic genotoxic effect. The treatment with piperine reduced this effect after $48 \mathrm{~h}$ (Figure 3). Micronuclei inside normochromatic erythrocytes were observed in Figure 4A,B. According to Reddy et al. [55], the percentage of polychromatic erythrocytes (PCEs; 
immature) among the erythrocytes must be determined in order to evaluate the cytotoxicity in the bone (in mammal assays). In mice, bone marrow toxicity is generally associated with the depression of spinal erythrocytes by approximately $80 \%$ or more of the control value. Although there are no published data for such an analysis in broilers, an estimation of the same calculation for broilers would give a bone marrow depression of $73.6 \%$ in Group $\mathrm{A}$ (receiving $\mathrm{AFB}_{1}$ alone), indicating a possible toxic effect on the spinal cord (Figure 4A,B). Toxic heterophils from broiler chickens intoxicated with aflatoxin $B_{1}$ are seen in Figure $4 C, D$. An increase in the number of immature heterophils occurs mostly in severe bacterial infections, mycobacteriosis, aspergillosis, chlamydiosis, and severe tissue necrosis resulting from trauma or neoplasia. The presence of toxic heterophils suggests toxemia [56]. As can be observed in this work, greater quantities of toxic heterophils were present in the group receiving $\mathrm{AFB}_{1}$ alone (Group $\mathrm{A}$ ) compared with the group receiving piperine (Group P) as well Group $\mathrm{P}+\mathrm{A}$ (Figure 4C,D).
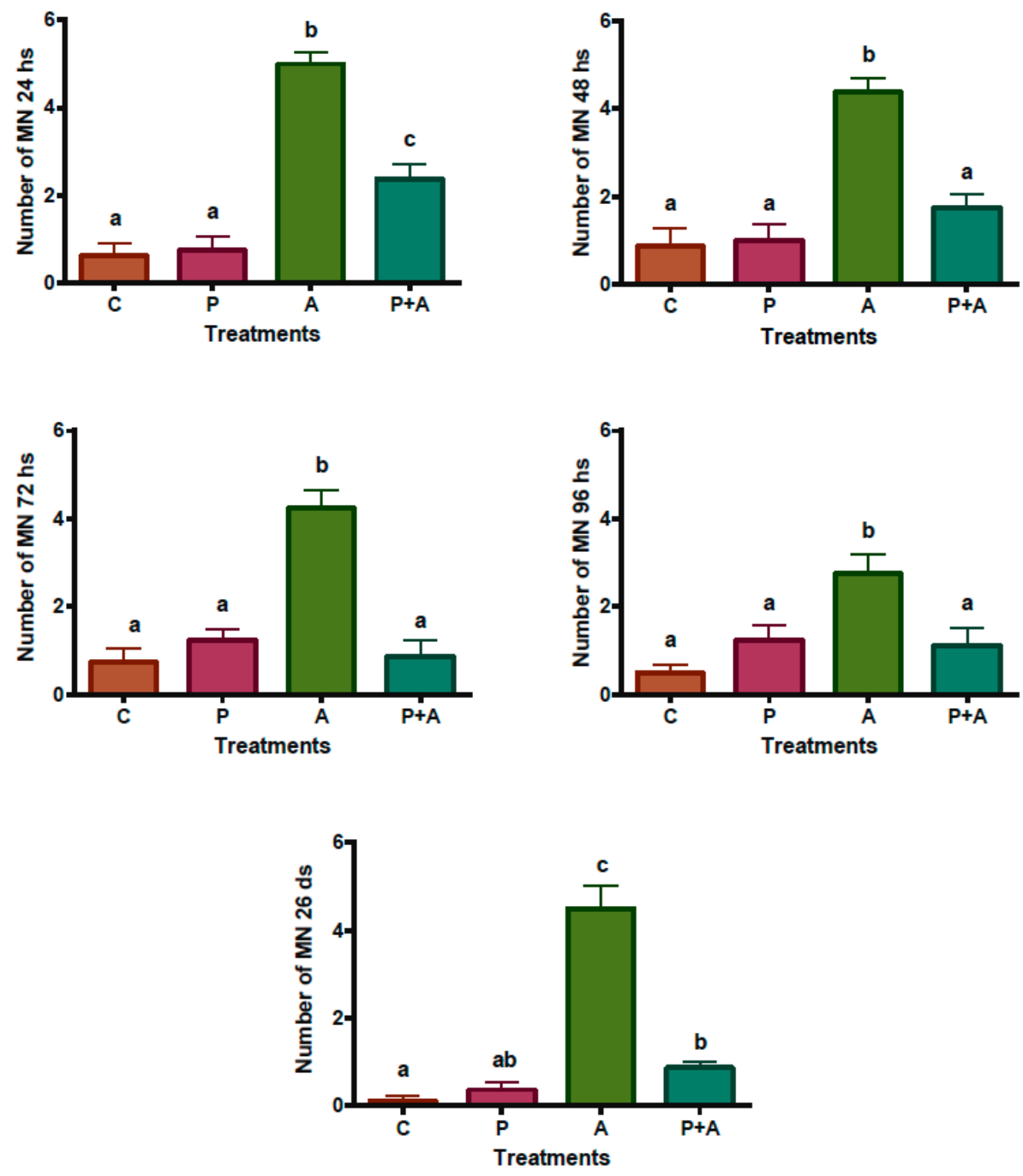

Figure 3. Square root of the micronuclei mean, evaluated in 2000 erythrocytes from peripheral blood samples of broiler chickens. C: Control; P: $60 \mathrm{mg} \cdot$ piperine $\cdot \mathrm{kg}^{-1}$ feed; A: $0.5 \mathrm{mg} \cdot \mathrm{AFB}_{1} / \mathrm{kg}$ body weight; $\mathrm{P}+\mathrm{A}: 60 \mathrm{mg} \cdot$ piperine $\cdot \mathrm{kg}^{-1}$ feed plus $0.5 \mathrm{mg} \cdot \mathrm{AFB}_{1} / \mathrm{kg}$ body weight; at $24,48,72$, and $96 \mathrm{~h}$, and 26 days. Data were normalized after processing the roots. ${ }^{\mathrm{a}-\mathrm{c}}$ Means and standard deviation (error bars) compared by the Student-Newman-Keuls test; means with the same letters are not statistically different $(p>0.05)$. 


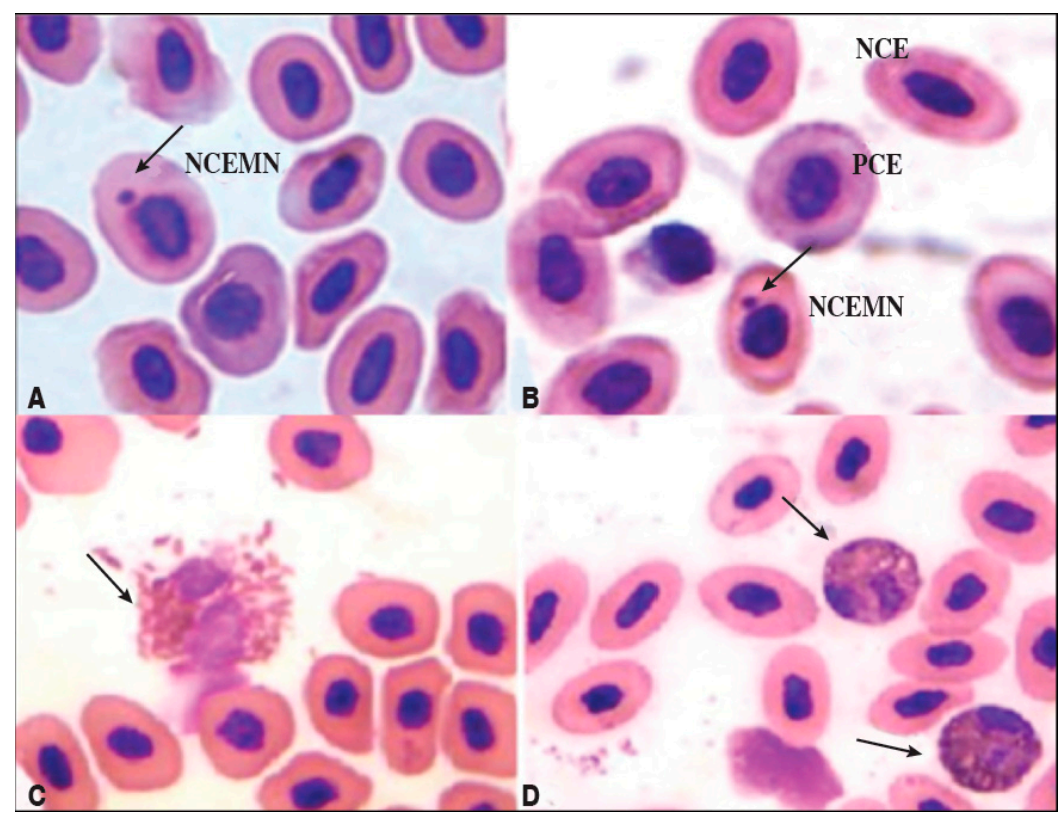

Figure 4. Photomicrographs of erythrocytes and heterophils. The cells were viewed under an optical microscope (Olympus ${ }^{\circledR}$ CH30RF 100, Olympus Corporation, Tokyo, Japan) at a magnification of $1000 \times$. (A) NCEMN: normochromatic erythrocytes with micronuclei (indicated by the arrow); PCE: polychromatic erythrocytes; (B) NCE: normochromatic erythrocytes, from peripheral blood of the group of chickens intoxicated with aflatoxin $\mathrm{B}_{1}\left(0.5 \mathrm{mg} \cdot \mathrm{AFB}_{1} \cdot \mathrm{kg}^{-1}\right.$ body weight); (C) Severe heterophil toxicity (arrow) seen in blood smears taken from broiler chickens intoxicated with aflatoxin $\mathrm{B}_{1}$. (D) Mild heterophil toxicity (arrow) observed in blood smears of broiler chickens that received both $60 \mathrm{mg} \cdot$ piperine $\cdot \mathrm{kg}^{-1}$ feed and $0.5 \mathrm{mg} \cdot \mathrm{AFB}_{1} \cdot \mathrm{kg}^{-1}$ body weight.

The group receiving $\mathrm{AFB}_{1}$ alone showed a significant reduction in the polychromatic-tonormochromatic erythrocyte ratio (PCE/NCE), in relation to the other groups and the time of treatment (Table 2). $\mathrm{AFB}_{1}$ obviously promoted the involvement of erythropoiesis, as confirmed by the reduction in the PCE/NCE ratio and the promotion of DNA damage. This effect was detected $24 \mathrm{~h}$ after intoxication (1st analysis).

Table 2. Ratio of polychromatic erythrocytes to normochromatic erythrocytes (PCE/NCE) from a total of 1000 erythrocytes of broiler chickens.

\begin{tabular}{cccccc}
\hline \multicolumn{7}{c}{ Treatment (Mean \pm SD) } \\
\hline Time & CONTROL & PIPERINE (P) & AFB $_{\mathbf{1}}$ (A) & P + A & CV (\%) * \\
\hline $24 \mathrm{~h}$ & $0.097^{\mathrm{a}} \pm 0.027$ & $0.081^{\mathrm{a}} \pm 0.024$ & $0.045^{\mathrm{b}} \pm 0.011$ & $0.070^{\mathrm{a}} \pm 0.016$ & 28.14 \\
$48 \mathrm{~h}$ & $0.107^{\mathrm{a}} \pm 0.029$ & $0.089^{\mathrm{a}} \pm 0.010$ & $0.060^{\mathrm{b}} \pm 0.017$ & $0.096^{\mathrm{a}} \pm 0.018$ & 21.57 \\
$72 \mathrm{~h}$ & $0.130^{\mathrm{a}} \pm 0.036$ & $0.126^{\mathrm{a}} \pm 0.027$ & $0.075^{\mathrm{b}} \pm 0.071$ & $0.116^{\mathrm{a}} \pm 0.024$ & 27.10 \\
$96 \mathrm{~h}$ & $0.153^{\mathrm{a}} \pm 0.036$ & $0.149^{\mathrm{a}} \pm 0.038$ & $0.084^{\mathrm{b}} \pm 0.025$ & $0.156^{\mathrm{a}} \pm 0.021$ & 22.99 \\
26 days & $0.268^{\mathrm{a}} \pm 0.020$ & $0.263^{\mathrm{a}} \pm 0.024$ & $0.062^{\mathrm{b}} \pm 0.018$ & $0.246^{\mathrm{a}} \pm 0.017$ & 13.68 \\
\hline
\end{tabular}

Note: Statistical analysis of the data was done by analysis of variance with means compared by the Student-Newman-Keuls test. ${ }^{\mathrm{a}, \mathrm{b}}$ in the rows, means followed by different letters differ statistically $(p<0.05)$. * CV: coefficient of variation; SD: standard deviation.

Any toxic effect in the bone marrow can be measured by a decrease in PCE (immature) levels, indicating a failure of production of red blood cells from the bone marrow. Therefore, the PCE level provides a fault indicator parameter of red blood cell production by the bone marrow [57]. 
The results of these piperine evaluations in this study show the potential for exploration in future studies. However, owing to the high coefficients of variation observed in our study, it is important to use the largest possible number of replicates per treatment.

\section{Conclusions}

Prolonged intoxication of broilers to $\mathrm{AFB}_{1}$ caused lesions characteristic of aflatoxicosis, including DNA damage and bone marrow blood production errors. Daily supplementation with $60 \mathrm{mg} \cdot \mathrm{kg}^{-1}$ of piperine in the diet of intoxicated broiler chickens ingesting $0.5 \mathrm{mg} \cdot \mathrm{AFB}_{1} \cdot \mathrm{kg}^{-1}$ body weight was able to reduce or even prevent the genotoxic and cytotoxic effects. Thus, piperine as a feed supplement appears to be a safe option to protect and help improve the health of broiler chickens.

\section{Experimental Section}

\subsection{Materials}

\subsubsection{Broiler Feed}

The feed administered to the boilers was dry and made in a vertical mash mixer. First the piperine was solubilized in soy oil and then added to the feed with the other ingredients which were described by Cardoso et al. [31].

\subsubsection{Preparation of Piperine}

Piperine was obtained according to the method of Ikan [26], at a 5\%-7\% yield and with high purity ( $98 \%)$. Gas chromatography coupled to mass spectrometry (GC-MS) showed it to have a melting temperature of $128-129^{\circ} \mathrm{C}$ and spectral data identical to those reported in the literature [58].

\subsubsection{Addition of Piperine to Broiler Feed}

Piperine incorporated into broiler feed was evaluated by GC-MS. Mycotoxicological analysis of the feed was performed before the experiments, according to the method of Soares and Rodriguez-Amaya [59], so that no changes in the immunological and hematological parameters could be affected by mycotoxins already present in the components of the feed (grain). The broiler feed including the corn grains used to prepare the feed contained less than the detection limits for the aflatoxin $\mathrm{B}_{1}$ monitored.

The composition of ingredients and nutritional requirements of the experimental chicken diet were obtained from Rostagno [60]. The piperine-containing feed was prepared in two phases: phase 1: encompassing the period between 9 and 21 days and phase 2: the beginning of the growth phase 22 to 35 days. In the initial stages (1-8 days) the feed was prepared without piperine.

\subsubsection{Aflatoxin $\mathrm{B}_{1}$}

Aflatoxin $B_{1}$ was obtained from cultures of Aspergillus parasiticus (CMDB 0336; origin: NRRL 2999) grown on yeast extract-sucrose agar for 11 days at $25{ }^{\circ} \mathrm{C}$. After this period, the cultures were subjected to chloroform extraction ( $50 \mathrm{~mL} /$ plate). The extract was filtered through Whatman filter paper No. 1 and then concentrated on a rotary evaporator to give a residue. The dried extract was then diluted in $1.0 \mathrm{~mL}$ of chloroform and analyzed by thin-layer chromatography (TLC) on silica gel chromatography sheets $(20 \times 20 \mathrm{~cm}, 0.3 \mathrm{~mm}$ thick; Merck, Merck, Darmstadt, Germany). The extracts were separated with a mobile phase consisting of toluene/chloroform/ethyl acetate/formic acid 90\% (70:50:50:20, $v / v / v / v$ ). The purified $\mathrm{AFB}_{1}$ was obtained by preparative TLC using silica gel (Silica Gel 60 G; Merck) on $20 \times 20 \mathrm{~cm}$ glass chromatography plates. The mobile phase was a mixture of chloroform and acetone $(90: 10, v / v)$ for better resolution with respect to the interference present in the extracts.

The $\mathrm{AFB}_{1}$ was quantified by high-performance liquid chromatography (Waters ASSOC., Milford, MA, USA) equipped with a Waters pump (model 510), Rheodyne injector (Rheodyne ${ }^{\circledR}$; with a $20 \mu \mathrm{L}$ 
loop, Rohnert Park, CA, USA), Agilent 1100 Series fluorescence detector (Agilent Technologies, Waldbronn, Germany), UV-VIS Merck-Hitachi L-4250 detector (Merck-Hitachi, Burladingen, Germany) and D-2500 Chromato-integrator (Hitachi, Tokyo, Japan), as well as Silica $5 \mu(4.6 \times 150 \mathrm{~mm}$ ) and

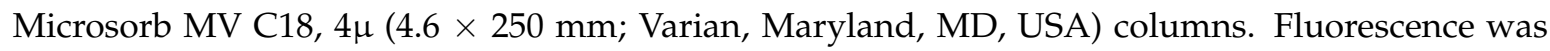
detected with excitation at $330 \mathrm{~nm}$ and emission at $460 \mathrm{~nm}$, and compared with Ultraviolet (UV) detection at $350 \mathrm{~nm}$. The mobile phases used were ethyl acetate $/ n$-hexane $(3: 2.5, v / v)$ at a flow rate of $2.0 \mathrm{~mL} / \mathrm{min}$ for detection by fluorescence, and methanol/water $(1: 1, v / v)$ at a flow rate of $0.7 \mathrm{~mL} / \mathrm{min}$ for detection by UV. The dried extracts were quantified and kept in a freezer until administered to the broiler chickens. The $\mathrm{AFB}_{1}$ solutions administered to the broilers were obtained by dissolving the dry extracts with a known volume of soybean oil (solvent carrier) and homogenizing with ultrasound for $30 \mathrm{~min}$ at $60{ }^{\circ} \mathrm{C}$. Aliquots of these solutions were prepared in the concentration of $0.5 \mathrm{mg} \cdot \mathrm{kg}^{-1}$ body weight of chicken and administered daily by gavage, starting with a 10-day-old broiler. The methodology was adapted from Gagini et al. [43].

The $\mathrm{AFB}_{1}$ obtained from cultures was prepared using the methodology described in the Official Methods Manual of the Association of Official Analytical Chemistry (AOAC). AFB 1 by Sigma was used as a standard solution [61]. Broilers were weighed daily during the trial so that the concentration of $\mathrm{AFB}_{1}$ administered satisfied the amount of $0.5 \mathrm{mg} \cdot \mathrm{kg}^{-1}$ body weight. The $\mathrm{AFB}_{1}$ was administered daily to the broilers of Groups A and P + A as of 10 days old until the age of 35 days, which was the last day of the experiment.

\subsubsection{Chick Treatments}

The experiment was conducted with 60 male chicks (9 days old) of the commercial strain Avian Cobb 500. After 9 days the intestinal tract of the broilers are physiologically mature so the broilers were adapted for 8 days before beginning the experiments [62]. The chicks were randomly divided into four groups (five broilers/cage) with three replications $(3 \times 5 / n=15)$ as follows: Group C were chicks that received only the vehicle (soybean oil) used in the gavage for the $\mathrm{AFB}_{1}$ treatment and diet without piperine; Group P comprised chicks that received only piperine $\left(60 \mathrm{mg} \cdot \mathrm{kg}^{-1} \mathrm{feed}\right)$ added to the diet and the vehicle (soybean oil) used in the gavage daily; Group A comprised chicks treated with $\mathrm{AFB}_{1}$ only $\left(0.5 \mathrm{mg} \cdot \mathrm{kg}^{-1}\right.$ body weight $)$ by gavage daily and diet without piperine; and Group P + A comprised chicks treated with $\mathrm{AFB}_{1}\left(0.5 \mathrm{mg} \cdot \mathrm{kg}^{-1}\right.$ body weight) by gavage and fed a diet containing piperine $\left(60 \mathrm{mg} \cdot \mathrm{kg}^{-1}\right.$ feed) daily. The aflatoxin was given to broilers which were weighed daily. The doses of piperine and AFB1 used were in accordance with Cardoso et al. [31,44].

\subsubsection{Broiler Performance}

The following production indexes were determined at initial (9-21 days), growth (22-35 days) and total period (9-35 days of age): feed intake, weight gain and feed conversion rate from the treatments groups as described in Section 4.1.5.

\subsubsection{Genotoxicity Assay}

Genotoxicity (based on the comet assay, presence of micronuclei, and frequency of polychromatic erythrocytes) was evaluated using blood samples collected at intervals of $24,48,72$, and $96 \mathrm{~h}$ from the first day of intoxication as well as on day 26 .

The comet assay followed the protocol described by Singh et al. [63] and Tice et al. [64] with some modifications. The blood samples $(1.0 \mathrm{~mL}$ each) were collected by ulnar vein puncture, using ethylene diamine tetra acetic acid (EDTA) as the anticoagulant. Ten milliliters of the blood sample was homogenized in $160 \mathrm{~mL}$ of low-melting point agarose. After homogenization, the mixture was carefully dispensed between two slides that had both been previously covered with a film of normal-melting point agarose $(1.5 \%, v / v$, in buffered saline). The slides were covered with a coverslip $(60 \times 25 \mathrm{~mm})$ and placed in the refrigerator for 10-20 min. Thereafter, the coverslips were removed and the slides were immersed for $24 \mathrm{~h}$ in a vat containing a cold lysis solution $(2.5 \mathrm{M} \mathrm{NaCl}, 100 \mathrm{mM}$ EDTA, $10 \mathrm{mM}$ Tris, 
$10 \%$ dimethyl sulfoxide, and 1\% Triton X-100; $\mathrm{pH} 10)$. Subsequently, the slides were transferred into an electrophoresis buffer ( $300 \mathrm{mM} \mathrm{NaOH}$ and $1 \mathrm{mM}$ EDTA, $\mathrm{pH}>13)$ for $20 \mathrm{~min}$ at $4{ }^{\circ} \mathrm{C}$. The electrophoresis was carried out at $25 \mathrm{~V}$ and $300 \mathrm{~mA}$ for $20 \mathrm{~min}$. Then the slides were neutralized in $0.4 \mathrm{M}$ Tris buffer for $5 \mathrm{~min}$, fixed in absolute ethanol for $2 \mathrm{~min}$, and finally stored in the dark at room temperature. For the analysis, the samples were stained with ethidium bromide $(20 \mathrm{~mL} / \mathrm{mL})$ and examined under an epifluorescence microscope (Olympus BX41, Olympus Corporation, Tokyo, Japan), using a 40× objective, an excitation filter of 516-560 $\mathrm{nm}$ and an emission filter of $590 \mathrm{~nm}$. One hundred cells were examined per animal; by calculating an average of 50 cells per slide (two slides).

Cells were analyzed according to the integrity of the core and the length of the tail formed, as described by [64]. The nucleoids analyzed were classified according to the degree of injury, following the method of Souza and Fontanetti [65]. The comet test results was carried out by assigning numerical values (0-3) for each of the classes of harm to each individual. One hundred cells of each broiler were examined as follows: (A) Class 0, control group fed soybean vehicle carrier only; (B) Class 1, control group fed $60 \mathrm{ppm}$ piperine; (C) Class 2, group with piperine and $0.5 \mathrm{mg}$ aflatoxin $\mathrm{B}_{1} \cdot \mathrm{kg}^{-1}$ body weight; (D) Class 3 , group with aflatoxin $\mathrm{B}_{1}$ only.

For the micronucleus test and evaluation of the frequency of polychromatic and normochromatic erythrocytes, two peripheral blood smears of each broiler were fixed in methanol (10xx0\%) for $15 \mathrm{~min}$. Then the slides were washed in distilled water and stained with 5\% Giemsa stain. After drying, the slides were coded and stored in boxes at room temperature. Chromosomal analysis was performed by using an optical microscope (Olympus ${ }^{\circledR C H}$ 30RF 100, Olympus Corporation, Tokyo, Japan at $1000 \times$ magnification, where 1000 cells were counted per slide (two slides/broiler) [66,67]. The slides were analyzed blind for the number of polychromatic erythrocytes (PCEs), normochromatic erythrocytes (NCEs), polychromatic erythrocytes with micronuclei (MNPCEs), and normochromatic erythrocytes with micronuclei (MNNCEs). The micronuclei were identified by following the criteria adapted from the Organisation for Economic Co-Operation and Development (OECD) Test No. 474, 2014 for in vivo micronucleus tests for mammal cells [68] and by Al-Sabti and Metcalfe for fish cells [69].

At the end of the experiment (after 26 consecutive days), the broiler chickens were weighed and slaughtered in accordance with rules established by Ministry of Agriculture, Livestock and Supply, (MAPA). The experiment was carried out with 96 one-day-old male Cobb chicks housed in an experimental shed.

\subsubsection{Statistical Analysis}

All values obtained were expressed as the mean \pm standard deviation (SD). The statistical significance of different parameters between treatment groups was analyzed by analysis of variance, followed by the Student-Newman-Keuls test for comparison between means. For the micronucleus test, the calculated mean and SD for each group were analyzed using the Student-Newman-Keuls test. Statistical analysis of the comet test results was carried out by assigning numerical values (0-3) for each of the classes of harm to each individual, respectively. After obtaining the frequencies of the classes, the sum of the scores was calculated to compare the results between control group and the tests groups. The differences were considered statistically significant when the $p$ value was $<0.05$. The software package GraphPad Prism 5.0 (version 5.0 for Windows, GraphPad Software, Inc., San Diego, CA, USA, 2010).

\subsection{Ethical Statement}

The studies involving the broiler chickens used in this study were conducted under veterinary supervision and in accordance with the normative instruction No. 3 of 17/01/2000 of the Ministry of Agriculture, Livestock and Supply, MAPA [70]. (http:/extranet.agricultura.gov.br/sislegis-consulta/ consultarlegislacao.do). All experiments were approved by the Animal Care and Use Committee of Instituto de Veterinária, Universidade Federal Rural do Rio de Janeiro, Seropédica, RJ, Brasil (identification code: 23083007814, date of approval: 18 December, 2008). 
Acknowledgments: The authors wish to acknowledge the Brazilian National Council for Scientific and Technological Development (MCT-CNPq), Carlos Chagas Filho Foundation for Research Support in the State of Rio de Janeiro (FAPERJ), Coordination for the Improvement of Higher Education Personnel (CAPES).

Author Contributions: V.d.S.C., M.d.G.M.D., G.M.D. and C.A.R.d.L. conceived and designed the experiments; V.d.S.C., M.E.F.d.L. and J.M.d.O. performed the experiments; C.A.R.d.L., L.H.P.d.S., G.M.D. and M.E.F.d.L. contributed reagents/materials/analysis tools; A.B.V., V.d.S.C., M.d.G.M.D., G.M.D. and C.A.R.d.L. analyzed the data and wrote the paper.

Conflicts of Interest: The authors declare no conflict of interest.

\section{References}

1. Council of Agricultural Science and Technology (CAST). Mycotoxins: Risks in Plant, Animal and Humans; Richard, J.L., Payne, G.A., Eds.; Task Force Report No. 139; Council of Agricultural Science and Technology (CAST): Ames, IA, USA, 2003; p. 199.

2. Oswald, I.P.; Marin, D.E.; Bouhet, S.; Pinton, P.; Taranu, I.; Accensi, F. Immunotoxicological risk of mycotoxins for domestic animals. Food Addit. Contam. 2005, 22, 354-360. [CrossRef] [PubMed]

3. Tessari, E.N.C.; Cardoso, A.L.S.P. A Aflatoxina em frangos de corte. Available online: http://www.biologico. sp.gov.br/artigos_ok.php?id_artigo=78 (accessed on 29 October 2016). (In Portuguese)

4. Bailey, G.S.; Williams, D.E.; Wilcox, J.S.; Loveland, P.M.; Coulombe, R.A.; Hendricks, J.D. Aflatoxin B 1 carcinogenesis and its relation to DNA adduct formation and adduct persistence in sensitive and resistant salmonid fish. Carcinogenesis 1988, 9, 1919-1926. [CrossRef] [PubMed]

5. Kubena, L.F.; Harvey, R.B.; Bailey, R.H.; Buckley, A.S.; Rottinghaus, G.E. Effects of hydrated sodium calcium aluminosilicate (T-Bind ${ }^{\mathrm{TM}}$ ) on mycotoxicosis in young broiler chickens. Poult. Sci. 1998, 77, 1502-1509. [CrossRef] [PubMed]

6. Parlat, S.S.; Yildiz, A.O.; Oguz, H. Effects of clinoptilolite on fattening performance of Japanese quail (Coturinix coturnix japonica) during experimental aflatoxicosis. Br. Poult. Sci. 1999, 40, 495-500. [CrossRef] [PubMed]

7. Babu, D.; Muriana, P.M. Sensitive quantification of aflatoxin $B_{1}$ in animal feeds, corn feed grain, and yellow corn meal using immunomagnetic bead-based recovery and real-time immunoquantitative-PCR. Toxins 2014, 12, 3223-3237. [CrossRef] [PubMed]

8. Coulombe, R.A. Aflatoxins. In Mycotoxins and Phytoallexins; Sharma, R.P., Salunkhe, D.K., Eds.; CRC Press: BocaRaton, FL, USA, 1991; pp. 103-143.

9. Ziringue-Junior, H.J.; Bhatnagar, D.; Cleveland, T.E. C15H24 volatile compounds unique to aflatoxigenic strains of Aspergillus flavus. Appl. Environ. Microbiol. 1993, 59, 2264-2270.

10. Rawal, S.; Kim, J.E.; Coulombe-Junior, R. Aflatoxin $B_{1}$ in poultry: Toxicology, metabolism and prevention. Res. Vet. Sci. 2010, 89, 325-331. [CrossRef] [PubMed]

11. Sabino, M. Variações de níveis de aflatoxina $B_{1}$ em alimentos, rações animais no período de 1971 a 1979. Rev. Inst. Adolfo Lutz 1980, 40, 153-158. (In Portuguese)

12. Rodriguez-Amaya, D.B.; Sabino, M. Mycotoxin research in Brazil: The decade in review. Braz. J. Microbiol. 2002, 33, 1-11. [CrossRef]

13. Ono, E.Y.S.; Mendes, A.M.; Meirelles, P.G.; Hirooka, E.Y.; Ono, M.A. Micotoxinas em alimentos. Biotecnol. Cienc. Desenvolv. 2004, 32, 69-80. (In Portuguese)

14. Greco, M.V.; Franchi, M.L.; Rico Golba, S.L.; Pardo, A.G.; Pose, G.N. Mycotoxins and Mycotoxigenic Fungi in Poultry Feed for Food-Producing Animals. Sci. World J. 2014, 2014, 968215. [CrossRef] [PubMed]

15. Guo, B.; Chen, Z.Y.; Lee, R.D.; Scully, B.T. Drought stress and preharvest aflatoxin contamination in agricultural commodity: Genetics, genomics and proteomics. J. Integr. Plant Biol. 2008, 50, 1281-1291. [CrossRef] [PubMed]

16. Madrigal-Santillán, E.; Morales-González, J.A.; Vargas-Mendoza, N.; Reyes-Ramírez, P.; Cruz-Jaime, S.; Sumaya-Martínez, T.; Pérez-Pastén, R.; Madrigal-Bujaidar, E. Antigenotoxic studies of different substances to reduce the DNA damage induced by aflatoxin $B_{1}$ and ochratoxin A. Toxins 2010, 4, 738-757. [CrossRef] [PubMed]

17. Lin, W.C.; Liao, Y.C.; Liau, M.C.; Lii, C.K.; Sheen, L.Y. Inhibitory effect of CDA-II, a urinary preparation, on aflatoxin $\mathrm{B}_{1}$-induced oxidative stress and DNA damage in primary cultured rat hepatocytes. Food Chem. Toxicol. 2006, 44, 546-551. [CrossRef] [PubMed] 
18. Reddy, L.; Odhav, B.; Bhoola, K. Aflatoxin $\mathrm{B}_{1}$-induced toxicity in HepG2 cells inhibited by carotenoids: Morphology, apoptosis and DNA damage. Biol. Chem. 2006, 387, 87-93. [CrossRef] [PubMed]

19. Abdel-Wahhab, M.A.; Hassan, N.S.; El-Kady, A.A.; Khadrawy, Y.A.; El-Nekeety, A.A.; Mohamed, S.R.; Hafiza, A.S.; Mannaa, F.A. Red ginseng extract protects against aflatoxin $B_{1}$ and fumonisins-induced hepatic pre-cancerous lesions in rats. Food Chem. Toxicol. 2010, 48, 733-742. [CrossRef] [PubMed]

20. Iamarcovai, G.; Botta, A.; Orsiére, T. Number of centromeric signals on micronuclei and mechanisms of aneuploidy. Toxicol. Lett. 2007, 166, 1-10. [CrossRef] [PubMed]

21. Fenech, M.; Holland, N.; Chang, W.P.; Zeiger, E.; Bonassi, S. The human micronucleus project-an international collaborative study on the use of the micronucleus technique for measuring DNA damage in humans. Mutat. Res. 1999, 428, 271-283. [CrossRef]

22. Nesslany, F.; Zennouche, N.; Simar-Neintieres, S.; Talahari, I.; Nkilimboui, E.M.; Marzin, D. In vivo comet assay on isolated kidney cells to distinguish genotoxic carcinogens from epigenetic carcinogens or cytotoxic compounds. Mutat. Res. 2007, 63, 28-41. [CrossRef] [PubMed]

23. Belpaeme, K.; Cooreman, K.; Kirsch-Volders, M. Development and validation of the in vivo alkaline comet assay for detecting genomic damage in marine flatfish. Mutat. Res. 1998, 415, 167-184. [CrossRef]

24. Najafi, P.; Torki, M. Performance, blood metabolites and immunocompetence of broiler chicks fed diets included essential oils of medicinal herbs. J. Anim. Vet. Adv. 2010, 9, 1164-1168.

25. Zhang, J.; Zhu, X.; Li, H.; Li, B.; Sun, L.; Xie, T.; Zhu, T.; Zhou, H.; Ye, Z. Piperine inhibits proliferation of human osteosarcoma cells via G2/M phase arrest and metastasis by suppressing MMP-2/-9 expression. Int. Immunopharm. 2015, 24, 50-58. [CrossRef] [PubMed]

26. Ikan, R. Natural Products. A laboratory Guide, 2nd ed.; Academic: New York, NY, USA, 1991; p. 316.

27. Dogra, R.K.; Khanna, S.; Shanker, R. Immunotoxicological effects of piperine in mice. Toxicology 2004, 196, 229-236. [CrossRef] [PubMed]

28. Pathak, N.; Khandelwal, S. Modulation of cadmium induced alterations in murine thymocytes by piperine: Oxidative stress, apoptosis, phenotyping and blastogenesis. Biochem. Parmacol. 2006, 72, 486-497. [CrossRef] [PubMed]

29. Pathak, N.; Khandelwal, S. Comparative efficacy of piperine, curcumin and picroliv against Cd immunotoxicity in mice. Biometals 2008, 6, 649-661. [CrossRef] [PubMed]

30. Cardoso, V.S.; Lima, C.A.R.; Lima, M.E.F.; Dorneles, L.E.G.; Teixeira-Filho, W.L.; Lisboa, R.S.; Guedes-Junior, D.S.; Direito, G.M.; Danelli, M.G.M. Administração oral de piperina em frangos de corte. Cienc. Rural 2009, 39, 1521-1526. (In Portuguese) [CrossRef]

31. Cardoso, V.S.; Lima, C.A.R.; Lima, M.E.F.; Dorneles, L.E.G.; Direito, G.M.; Danelli, M.G.M. Piperine as a phytogenic additive in broiler diets. Pesqui. Agropecu. Bras. 2012, 47, 489-496. [CrossRef]

32. Estrela, J.L.; Guedes, R.N.; Maltha, C.R.; Fazolin, M. Toxicity of piperine amide analogs to larvae of Ascia monuste orseis Godart (Lepidoptera: Pieridae) and Spodoptera frugiperda (JE Smith) (Lepidoptera: Noctuidae). Neotrop. Entomol. 2003, 32, 343-346. [CrossRef]

33. Ghoshal, S.; Krishna, P.B.N.; Lakshmi, V. Antiamoebic activity of Piper longum fruits against Entamoeba histolytica in vitro and in vivo. J. Ethnopharmacol. 1996, 50, 167-170. [CrossRef]

34. Virinder, S.P.; Subash, C.J.; Kirpal, S.B.; Rajani, J. Phytochemistry of genus Piper. Phytochemistry 1997, 46, 597-673.

35. Mittal, R.; Gupta, R.L. In vitro antioxidant activity of piperine. Methods Find Exp. Clin. Pharmacol. 2000, 122, 163-167. [CrossRef]

36. Ahmad, N.; Fazal, H.; Abbasi, B.H.; Farooq, S.; Ali, M.; Khan, M.A. Biological role of Piper nigrum L. (Black pepper): A review. Asian Pac. J. Trop. Biomed. 2012, 2, S1945-S1953. [CrossRef]

37. Reen, K.R.; Wiebel, J.F.; Singh, J. Piperine inhibits aflatoxin $\mathrm{B}_{1}$-induced cytotoxicity and genotoxicity in V79 Chinese hamster cells genetically engineered to express rat cytochrome P4502B1. J. Ethnopharmacol. 1997, 58, 165-173. [CrossRef]

38. Bhat, B.G.; Chandrasekhara, N. Studies on the metabolism of piperine: Absorption, tissue, distribution and excretion of urinary conjugates in rats. Toxicology 1986, 40, 83-92. [CrossRef]

39. Suresh, D.; Srinivasan, K. Tissue distribution and elimination of capsaicin, piperine and curcumin following oral intake in rats. J. Med. Res. 2010, 131, 682-691. 
40. Greenshields, A.L.; Doucette, C.D.; Sutton, K.M.; Madera, L.; Annan, H.; Yaffe, P.B.; Allison, F.K.; Zhongmin, D.; Hoskin, D.W. Piperine inhibits the growth and motility of triple-negative breast cancer cells. Cancer Lett. 2015, 357, 129-140. [CrossRef] [PubMed]

41. Selvendiran, K.; Senthilnathan, P.; Magesh, V.; Sakthisekaran, D. Modulatory effect of Piperine on mitochondrial antioxidant system in Benzo(a)pyrene-induced experimental lung carcinogenesis. Phytomedicine 2004, 11, 85-89. [CrossRef] [PubMed]

42. Selvendiran, K.; Koga, H.; Ueno, T.; Yoshida, T.; Maeyama, M.; Torimura, T.; Hirohisa, Y.; Masamichi, K.; Sata, M. Luteolin promotes degradation in signal transducer and activator of transcription 3 in human hepatoma cells: An implication for the antitumor potential of flavonoids. Cancer Res. 2006, 66, 4826-4834. [CrossRef] [PubMed]

43. Gagini, T.B.; Silva, R.E.; Castro, I.S.; Soares, B.A.; Lima, M.E.F.; Brito, M.F.; Mazur, C.; Direito, G.M.; Danelli, M.G.M. Oral administration of piperine for the control of aflatoxin intoxication in rats. Braz. J. Microbiol. 2010, 41, 345-348. [CrossRef] [PubMed]

44. Cardoso, V.S.; Castro, I.S.; Lima, C.A.R.; Lima, M.E.F.; Dorneles, L.E.G.; Direito, G.M.; Danelli, M.G.M. Efficacy of piperine in reducing the effects of aflatoxin intoxication in broiler chickens: A preliminary report. Arquivo Brasileiro de Medicina Veterinária e Zootecnia 2011, 63, 495-498. [CrossRef]

45. Ministry of Agriculture (MAPA). Ordinance MA/SNAD/SFA No. 07 of 09/11/88; Official Gazette: Brasília, Brazil, 1988; Section I; pp. 219-268.

46. EC (Commission Regulation) No 2174/2003. Official Journal of the European Union; L326, 12-15. Available online: http:/ / eur-lex.europa.eu/legal-content/EN/TXT/?uri=CELEX:32003R2174 (accessed on 29 October 2016).

47. Food and Agriculture Organization (FAO). Worldwide Regulations for Mycotoxins 1995-A Compendium FAO Food and Nutrition Paper; FAO: Roma, Italy, 1997.

48. Rossi, C.N.; Takabayashi, C.R.; Ono, M.A.; Bordini, J.G.; Itano, E.N.; Kawamura, O.; Pinheiro, J.W.; Hirooka, E.Y.; Ono, E.Y.S. Exposure of laying hens to mycotoxins through naturally contaminated feed. World Mycotoxin J. 2013, 6, 199-207. [CrossRef]

49. Ammar, R.B.; Sghaier, M.B.; Boubaker, J.; Bhouri, W.; Naffeti, A.; Skandrani, I.; Bouhlel, I.; Kilani, S.; Ghedira, K.; Chekir-Ghedira, L. Antioxidant activity and inhibition of aflatoxin $\mathrm{B}_{1^{-}}$, nifuroxazide-, and sodium azide-induced mutagenicity by extracts from Rhamnus alaternus L. Chem. Biol. Interact. 2008, 174, 1-10. [CrossRef] [PubMed]

50. Yener, Z.; Celik, I.; Ilhan, F.; Bal, R. Effects of Urtica dioica L. seed on lipid peroxidation, antioxidants and liver pathology in aflatoxin-induced tissue injury in rats. Food Chem. Toxicol. 2009, 4, 418-424. [CrossRef] [PubMed]

51. Sotomayor, R.E.; Washington, M.; Nguyen, L.; Nyang'anyi, R.; Hinton, D.M.; Chou, M. Effects of intermittent exposure to aflatoxin $\mathrm{B}_{1}$ on DNA and RNA adduct formation in rat liver: Dose-response and temporal patterns. Toxicol. Sci. 2003, 73, 329-338. [CrossRef] [PubMed]

52. Heddle, J.A.; Cimino, M.C.; Hayashi, M.; Romagna, F.; Shelby, M.D.; Tucker, J.D.; Vanparys, P.H.; Macgregor, J.T. Micronuclei as an index of cytogenetic damage: Past, present, and future. Environ. Mol. Mutagen. 1991, 18, 277-291. [CrossRef] [PubMed]

53. Fenech, M.; Cheng, W.P.; Kirsch-Volders, M.; Holland, N.; Bonassi, S.; Zeiger, E. Humn project: Detailed description of the scoring criteria for the cytokinesis-block micronucleus assay using isolated human lymphocyte cultures. Mutat. Res. 2003, 534, 65-75. [CrossRef]

54. Udroiu, I. The micronucleus test in piscine erythrocytes. Aquat. Toxicol. 2006, 79, 201-204. [CrossRef] [PubMed]

55. Reddy, G.B.; Khandare, A.L.; Reddy, P.Y.; Rao, G.S.; Balakrishna, N.; Srivalli, I. Antioxidant defense system and lipid peroxidation in patients with skeletal fluorosis and in fluoride-intoxicated rabbits. Toxicol. Sci. 2003, 72, 363-368. [CrossRef] [PubMed]

56. Schimidt, S.E.M.; Locatelli-Dittrich, R.; Sautin, E.; Paulili, A.C. Patologia clínica em aves de produção-Uma ferramenta para monitorara sanidade avícola. Arch. Vet. Sci. 2007, 12, 9-20. (In Portuguese)

57. Wolf, T.; Luepke, N.P. Formation of micronuclei in incubated hen's eggs as a measure of Genotoxicity. Mutat. Res. 1997, 394, 163-175. [CrossRef]

58. Araujo-Junior, J.X.; Cunha, E.V.L.; Chaves, M.C.; Gray, A.I. Piperdardina, a piperidine alkaloid from Piper tuberculatum. Phytochemistry 1997, 44, 559-561. [CrossRef] 
59. Soares, L.M.V.; Rodriguez-Amaya, D.B. Survey of aflatoxins, ochratoxins A, zearalenona and sterigmatocystin in some Brazilian foods by multitoxin thin layer chromatographic method. J. Assoc. Off. Anal. Chem. 1989, 72, 22-26. [PubMed]

60. Rostagno, H.S.; Albino, L.F.T.; Donzele, J.L. Tabelas Brasileiras Para Aves e Suínos: Composição de Alimentos e Exigências Nutricionais; Universidade Federal de Viçosa: Viçosa, Brazil, 2005; p. 186. (In Portuguese)

61. Association of Official Analytical Chemistry (AOAC). Official Methods of Analysis, 17th ed.; AOAC: Washington, DC, USA, 2000.

62. Uni, Z.; Ganot, S.; Sklan, D. Posthatch development of mucosal function in the broiler small intestine. Poult. Sci. 1998, 77, 75-82. [CrossRef] [PubMed]

63. Singh, N.P.; Mccoy, M.T.; Tice, R.R.; Schneider, E.L. A simple technique for quantitation of low levels of DNA damage in individual cells. Exp. Cell Res. 1988, 175, 184-191. [CrossRef]

64. Tice, R.R.; Agurell, E.; Anderson, D.; Burlinson, B.; Hartmann, A.; Kobayashi, H.; Miyamae, Y.; Rojas, E.; Ryu, J.C.; Sasaki, Y.F. Single cell gel/Comet Assay: Guidelines for in vitro and in vivo genetic toxicology testing. Environ. Mol. Mutagen. 2000, 35, 206-221. [CrossRef]

65. Souza, T.S.; Fontanetti, C.S. Micronuleus test and observation of nuclear alterations in erythrocytes of Nile tilapia exposed to waters affected by refinery effluent. Mutat. Res. 2006, 605, 87-93. [CrossRef] [PubMed]

66. Campana, M.A.; Panzeri, A.M.; Moreno, V.J.; Dulout, F.N. Genotoxic evaluation of the pyrethroid lambda-cyhalothrin using the micronucleus test in erythrocytes of the fish Cheirodon interruptus interruptus. Mutat. Res. 1999, 438, 155-161. [CrossRef]

67. Grisolia, C.K. A comparison between mouse and fish micronucleus test using cyclophosphamide, mitomycin C and various pesticides. Mutat. Res. 2002, 518, 145-150. [CrossRef]

68. Organisation for Economic Co-Operation and Development (OECD). Guidelines for the Testing of Chemicals, Section 4: Health Effects. Test No. 474: Mammalian Erythrocyte Micronucleus Test. 2014. Available online: http://www.oecd-ilibrary.org/docserver/download/9714541e.pdf (accessed on 29 October 2016).

69. Al-Sabti, K.; Metcalfe, C.D. Fish micronuclei for assessing genotoxicity in water. Mutat. Res./Genet. Toxicol. 1995, 343, 121-135. [CrossRef]

70. Agência Nacional de Vigilância Sanitária (ANVISA). Resolução de Diretoria Colegiada -RDC n.17, de 24 de Fevereiro de 2000—Dispõe Sobre Registro de Fitoterápicos; Secretaria Nacional de Vigilância Sanitária, Ministério da Saúde: Brasília, Brasil, 2000. (In Portuguese)

(C) 2016 by the authors; licensee MDPI, Basel, Switzerland. This article is an open access article distributed under the terms and conditions of the Creative Commons Attribution (CC-BY) license (http://creativecommons.org/licenses/by/4.0/). 